\title{
Relative Adrenal Insufficiency in Pediatric Septic Shock
}

\author{
David Vila-Pérez ${ }^{1} \quad$ Iolanda Jordan-García ${ }^{1}$ \\ 1 Pediatric Intensive Care Unit, Barcelona University, Hospital Sant Joan \\ de Déu, Barcelona, Spain \\ Address for correspondence lolanda Jordan-García, MD, Hospital Sant \\ Joan de Déu, Passeig Sant Joan de Déu n² 2, 08950, Esplugues \\ Llobregat, Barcelona, Spain (e-mail: ijordan@hsjdbcn.org).
}

J Pediatr Intensive Care 2015;4:129-137.

\begin{abstract}
Keywords

- sepsis

- septic shock

- pediatric septic shock

- adrenal insufficiency

- relative adrenal insufficiency

Sepsis and septic shock represent important causes of morbidity and mortality in children, and adrenal dysfunction may play a role in the cardiovascular and immunological response. According to existing reports, the incidence of adrenal dysfunction in critically ill children varies significantly between 4 and $52 \%$ of patients. This article reviews the concept of adrenal insufficiency and the role it may play in a pediatric septic shock. Also discussed are the diagnosis, prognosis, and treatment of adrenal insufficiency in septic shock in adults and children. Finally, the latest recommendations about steroid use in pediatric septic shock are summarized.
\end{abstract}

\section{Introduction}

Sepsis and septic shock represent major causes of morbidity and mortality in children despite the significant improvements in pediatric critical care. International initiatives such as "Surviving Sepsis Campaign" have established that an early diagnosis and a prompt administration of adequate antibiotic treatment and resuscitation are the only measures that improve the prognosis. ${ }^{1,2}$

Despite these advances, the mortality of children with septic shock in developed countries is still above $12 \%{ }^{3}$ Most children present with shock refractory to fluid administration and infusion of inotropes. In recent years, the approach to sepsis has changed due to differences in predisposition, infection characteristics, host response, and organ dysfunction. ${ }^{4-8}$ In that sense, presence of adrenal insufficiency (AI) could be a predisposing factor that could lead to the organ dysfunction and may worsen the prognosis.

Hormonal regulation in septic patients is imbalanced, not only in the adrenal axis, but also in other hormones such as thyroxin and vasopressin. ${ }^{9}$ Moreover, the diagnosis of AI has been controversial and has led to numerous studies in adult population with conflicting results, but in pediatric population $\mathrm{AI}$ is not as well characterized and its diagnosis and the role of corticosteroid treatment are still under debate. ${ }^{10-13}$

received

July 15,2014

accepted after revision

October 10, 2014

published online

August 7, 2015
The aim of this study was to review more recent and relevant data regarding relative adrenal insufficiency (RAI) in pediatric patients. Published studies including reviews about RAI in septic shock in pediatric population were searched in the PubMed database.

\section{The Effects of Hydrocortisone}

Steroids produce their effect by binding to and activating a 90-kDa intracellular glucocorticoid receptor protein. ${ }^{14}$ It seems that all cells have substantial levels of this receptor, therefore enabling glucocorticoid to regulate gene transcription in every cell in the body and prepare the organism for stress.

For example, steroids increase blood glucose concentrations by increasing the rate of hepatic gluconeogenesis and inhibition of adipose tissue glucose uptake, facilitating the delivery of glucose during stress. ${ }^{15}$ This ensures energy and substrate supply to the cell, required for the response to stress and repair from injury. There are several other metabolic functions, but we will focus briefly on the maintenance of the cardiovascular system and the inflammatory effects of steroids.

It is well known that corticosteroids are important for maintenance of vascular tone, endothelial integrity, and

Copyright @ $\odot 2015$ by Georg Thieme Verlag KG, Stuttgart · New York
DOI http://dx.doi.org/ 10.1055/s-0035-1559821. ISSN 2146-4618. 
cardiac contractility to maintain cardiac output, and are required for normal reactivity to angiotensin II, epinephrine, and noradrenalin. ${ }^{16}$ Corticosteroids also lead to an increase in the number and sensitivity of $\alpha$ and $\beta$ adrenergic receptors, mediated by an increase in transcription for these receptors. Corticosteroids also maintain blood pressure by decreasing the production of nitric oxide, a major vasodilator and modulator of vascular permeability. ${ }^{17-25}$

In severe sepsis, the number and sensitivity of catecholamine receptors are altered, due to proinflammatory cytokines, which lead to catecholamine dysfunction and refractory hypotension. ${ }^{26}$ Prolonged use of exogenous catecholamine treatment will also result in a downward regulation of catecholamine receptors. ${ }^{27}$

There are in vitro and in vivo data that show corticosteroids help to reverse this process mediated by an increase in transcription of $\alpha$ and $\beta$ adrenergic receptors. ${ }^{21,22}$ In one study, cardiac index and myocardial receptor density of critically ill patients improved after administration of methylprednisolone. ${ }^{28}$ Other studies also showed reversal of this downward regulatory process with low-dose steroids. ${ }^{27}$ These findings are in keeping with the clinical observation of decreased inotropic requirements in patients treated with low-dose steroids.

Corticosteroids have a wide range of action on inflammatory processes. ${ }^{17-20,29,30}$ Corticosteroids induce increased expression of receptors for inflammatory cytokines on immune effector cells, including interleukin-1 (IL-1), IL-2, IL-4, IL-6, IL-7, and interferon- $\gamma$ as well as granulocyte-macrophage colony-stimulating factor. ${ }^{31-40}$ Steroids also stimulate phagocytosis in monocytes and neutrophils, proliferative responses of T-cells and macrophages, and tissue inflammatory responses to injury. ${ }^{35,41-44}$ In one study, endotoxin significantly increased plasma concentrations of IL-6, which has predominately proinflammatory effects, when participants were exposed to an intermediate dose of cortisol. ${ }^{45,46}$ This observation explains how a transient increase in plasma cortisol to intermediate stress-associated levels enhances subsequent endotoxininduced IL-6 production while decreasing IL-10 production, with predominant anti-inflammatory effects. ${ }^{45,47,48}$ In contrast, increases in plasma cortisol to higher levels had a substantially lesser effect on the plasma IL-6 response and no significant effect on the plasma IL-10 response. ${ }^{45}$ However, there is some evidence that the principal effect of hydrocortisone is as a mineralocorticoid and not as an anti-inflammatory modulator. ${ }^{49}$ Second, other studies found that low-dose hydrocortisone does have some clinically valuable anti-inflammatory effects and, in addition, enhances neutrophil phagocytosis. ${ }^{50}$

All these effects, considered stimulatory corticosteroids effects, have been observed at lower steroid concentrations, whereas higher steroid concentrations produced no effect or suppressive effects. ${ }^{51-57}$ In addition, the concentration of cortisol that is needed to effectively suppress ongoing systemic inflammation in vivo remains a matter of controversy. ${ }^{58}$

\section{Concept of Relative Adrenal Insufficiency}

In septic shock, an example of severe acute physical stress, normal or high levels of cortisol are found in blood samples. ${ }^{59,60}$ This observation has traditionally been attributed to stress-induced activation of the hypothalamic-pituitary-adrenal (HPA) axis and increased corticotrophin-driven cortisol production. ${ }^{61}$ Despite this stress response, patients may have RAI. ${ }^{10,11,62}$

Some studies have observed a paradoxical dissociation between cortisol and corticotrophin levels in stress conditions such as septic shock. ${ }^{63,64}$ During critical illness, proinflammatory cytokines could raise the levels of cortisol, and in some studies a paradoxical dissociation was found between cytokine levels and cortisol production. ${ }^{64,65}$ Other studies have found reduced cortisol breakdown due to suppressed expression and activity of cortisol-metabolizing enzymes that can contribute to hypercortisolemia and hence corticotrophin suppression. ${ }^{66}$

These findings suggest cortisol metabolism is more complicated than previously thought and could show other ways that the organism has to adapt to infection. In septic patients, with an understimulation of the hypothalamus-adrenal axis, the organism tries to adapt by cortisol production and by other pathways, in addition to a less effective elimination. That consideration could imply the acceptation of an RAI.

Reports led to the conviction that cortisol levels would raise according to the illness severity and we can differentiate two different groups in which the prognostic would be worse. One group presents low levels of cortisol despite a septic stress (classical AI) and the other group presents high levels with more severe disease but with a blunted cortisol response after adrenocorticotropic hormone (ACTH) stimulation (RAI). ${ }^{67}$ This discrepancy is due to a bimodal distribution of mortality in relation to random cortisol levels and could be explained by some degree of corticosteroid tissue resistance, where an impaired function of the corticosteroid receptor may play a role. ${ }^{68}$

Patients with low serum cortisol levels caused by HPA axis failure and patients with very high serum cortisol levels demonstrating maximal stimulation of the axis with possible relative steroid insufficiency have the worst prognosis. ${ }^{69}$

AI appears to be common both in septic and in nonseptic critically ill children; therefore, AI should be considered in hypotensive children even in the absence of known sepsis. ${ }^{70}$

\section{Diagnosis of Adrenal Insufficiency}

The incidence of adrenal dysfunction in critically ill children varies significantly, according to different existing reports, and represents up to $52 \%$ of patients. ${ }^{71-74}$ The six available pediatric studies focused primarily on children with septic shock. ${ }^{71-73,75}$ All six studies used different definitions for the diagnosis of $\mathrm{AI}$, making the results hard to compare and interpret in the broader context of pediatric critical care. $^{71-76}$ Indeed, significant variability in cortisol levels has been described, depending on the measurement methods used. ${ }^{77}$ However, there is no consensus among pediatric intensive care physicians or pediatric endocrinologists on diagnosis or treatment of $\mathrm{AI}$ in pediatric critical illness, even on its own existence. ${ }^{78}$ Multiple studies have shown that random cortisol levels alone may be inadequate for the 
detection of adrenal dysfunction despite the diurnal variation being lost in septic patients. ${ }^{72,79-82}$ In healthy volunteers, basal levels of cortisol were found to be $15 \mathrm{mg} / \mathrm{dL}$ in the morning. Basal cortisol levels were found to be higher in patients with fever, infection, severe infection, and septic shock than in healthy volunteers. As happens in stressful situations, administration of $1 \mu \mathrm{g}$ of ACTH increased cortisol levels above $18 \mathrm{mg} / \mathrm{dL}$. Hence, absolute AI could be diagnosed by basal cortisol levels below $4 \mathrm{mg} / \mathrm{dL}$ or ACTH stimulated levels below $18 \mathrm{mg} / \mathrm{dL}$. ${ }^{67}$

Diagnosing RAI is problematic. The cortisol levels found in survivors of septic shock or meningitis are higher than those found in persons with pneumonia or children with fever. ${ }^{71,83-85}$ Also, there are some reports that found higher cortisol levels in survivors rather than in nonsurvivors ${ }^{86}$; so when would an impaired response show? Most reports lead to cortisol levels that rise according to the illness severity above $18 \mathrm{mg} / \mathrm{dL}$, and patients with more severe disease would have a blunted cortisol response with an incremental increase under $9 \mathrm{mg} / \mathrm{dL}$ after ACTH stimulation. ${ }^{67}$ For the moment, the cutoff is most extended in the different studies. ${ }^{72,80,87-89}$

The corticotrophin test is also a matter of discussion. The standard test for the integrity of the HPA axis is the short Synacthen test, performed by administering $250 \mu \mathrm{g}$ of a synthetic ACTH, measuring cortisol at baseline and at 30 and 60 minutes. This test was developed to assess adrenal response in patients with intrinsic adrenal problems. ${ }^{69}$ As $250 \mu \mathrm{g}$ of Synacthen is the physiological dose, there are concerns that the sensitivity for the diagnosis of $\mathrm{AI}$ is not adequate, particularly as adult patients with a normal response to this test may still fail to respond adequately to stress. $^{69,90-92}$ Several studies suggested that the use of $1 \mu \mathrm{g}$ instead of $250 \mu \mathrm{g}$ is more sensitive and specific in the diagnosis of AI. ${ }^{73,93-102}$ Even mild degrees of AI would be detected in children using $0.5 \mu \mathrm{g}$ for each square meter of corporal surface that otherwise goes undetected by a standard dose short Synacthen test. ${ }^{102}$

The diagnosis of AI is based on measurements of total serum cortisol. Only $10 \%$ of total cortisol (TC) in the plasma is in the physiologically active unbound form. There is a decrease in cortisol binding capacity in critically ill patients with a subsequent increase in the free fraction. ${ }^{103}$ Moreover, studies have described the poor relationship between TC and free cortisol (FC) levels and other issues concerning the dose, timing, and type of corticotropin. ${ }^{104,105}$

Salivary cortisol estimation may offer some advantages over total serum cortisol; it represents the biologically active free fraction of cortisol and is a simple noninvasive technique. $^{106,107}$ There is a good correlation between salivary cortisol and free serum cortisol in adult patients with septic shock; however, no consensus exists as to what constitutes the lower limit of salivary cortisol in critically ill children. ${ }^{108}$

An evolving consensus suggests that FC, rather than protein-bound cortisol, is responsible for the protean actions of this hormone. ${ }^{104,109}$ Normally, cortisol-binding globulin (transcortin) and albumin bind 90\% of circulating cortisol. During critical illness, the concentrations of these proteins may decrease by $50 \%$, but individual variation is significant.
Both TC and FC concentrations, as well as FC as a percent of TC, were markedly higher among critically ill children compared with unstressed adult volunteers. ${ }^{81}$ Recognizing that concentrations of the cortisol-binding proteins may change considerably with critical illness with sepsis and septic shock, FC concentrations may correspond more closely to illness severity than TC. ${ }^{104,110}$

FC may also be measured directly from saliva samples, eliminating the need for serum or plasma fractionation. ${ }^{111}$ Salivary cortisol is in equilibrium and correlates with the free (unbound) fraction of the hormone in the circulation. Current data suggest that real-time FC quantification is possible to ultimately facilitate clinical decision making regarding cortisol replacement therapy for children with critical illness. ${ }^{81}$ Gender-specific morning salivary cortisol reference values have been published, ${ }^{112}$ but the problem is there are no reference values for the diagnosis of an absolute AI or an RAI. No consensus exists as to what constitutes the lower limit of salivary cortisol in critically ill children. However, in some studies that used a cutoff of $1.3 \mathrm{nmol} / \mathrm{L}$ salivary cortisol value, representing 25 th centile, absolute AI was diagnosed in $15.7 \%$ and RAI in $68.6 \%{ }^{113}$ Rates were similar to others.

The role that the corticosteroid tissue resistance plays provides more difficulty since no tests evaluate corticosteroid activity at tissue level. ${ }^{68}$ Despite the diagnosis of RAI, this will not mean the adrenal gland function is impaired forever; in fact, adrenal stimulation tests are a measure of adrenal reserve and not necessarily function. This distinction is important in a child with an elevated cortisol level but an inadequate change after a corticotrophin stimulation test. The inadequate response could be a marker of end organ resistance rather than inadequate hormone production, ${ }^{69,91}$ so a low cortisol response to ACTH may be a marker of severe disease and associated mortality. ${ }^{110,111,114}$

Despite these facts, in one study carried on in Canada, the majority of those surveyed about adrenal axis testing (64.8\%) stated that they performed random cortisol level testing. ${ }^{115}$ This may be related to difficulties conducting an ACTH stimulation test in an acute situation or the lack of clear evidence that ACTH stimulation testing is useful in the face of conflicting studies on the association of the results of adrenal testing with clinically important outcomes. ${ }^{79,81}$

\section{Studies in Adult and Pediatric Patients}

A known fact is that the presence of AI both in adults or in children with sepsis reduces survival and is a marker of bad prognostic. ${ }^{116}$ Despite biological plausibility and significant clinical interest, the use of corticosteroids in pediatric shock remains a controversy. ${ }^{117-119}$ There are several factors which contribute to the current degree of uncertainty among physicians and health care providers. First, there have been no large randomized clinical trials in children. Second, large adult studies on severe sepsis and shock provided conflicting results.

A 1995 meta-analysis done with adult patients found that a short course of high-dose glucocorticoid therapy provided no advantage for the treatment of septic shock and could have 
negative effects. ${ }^{120}$ A 2004 meta-analysis found that steroids did not affect mortality from septic shock. ${ }^{121}$ However, a subgroup analysis of patients treated with low doses of steroids ( $\leq 300 \mathrm{mg}$ hydrocortisone or equivalent per day) for more than 5 days found that sustained low-dose steroid therapy reduced 28-day mortality. In 2009, the same group of researchers repeated a meta-analysis on the same issue by integrating recent randomized controlled trials. ${ }^{122}$ The analysis was restricted only to the response to steroid therapy in an adult population with severe sepsis and septic shock. The results demonstrated long-term, low-dose steroid therapy can increase short-term survival rates. Most large metaanalysis done in adult population found an increase in shock reversal at 7 days with hydrocortisone statistically significant. $^{123}$

The literature on the use of steroids in pediatric shock is limited both in amount and in methodological quality, plus it demonstrates conflicting results. ${ }^{124}$ There is very limited evidence on which current guidelines in this area are based, and there is a strong need for a well-designed, pragmatic, randomized controlled trial on the use of steroids in pediatric shock to inform future guidelines.

- Table 1 shows the most relevant studies done, both in pediatric and in adult population, about AI or the use of steroids in septic shock. ${ }^{10,11,16,75,113,114,125-135}$

The two major studies on the use of corticosteroids in septic shock were the study conducted by Annane et $\mathrm{al}^{10}$ and the CORTICUS study. ${ }^{11}$ The first concluded that patients treated with low doses of corticosteroids had better survival and had an earlier withdrawal of inotropic therapy, especially in the group of "no responders" to corticotrophin stimulation. In the study of CORTICUS, no statistically significant difference was found in mortality between the group treated with low doses of corticosteroids and the group treated with placebo, despite being "no responders" to corticotrophin stimulation. Otherwise, patients treated with steroids recovered more quickly from the shock but also had more superinfections. ${ }^{11}$ In another study, conducted by de Jong et al, ${ }^{114}$ there were four groups according to the response to the corticotrophin test and the treatment with hydrocortisone. The mortality rate was higher in the groups with no response and the groups without treatment, and even higher with combination of both. In the same study, the treatment with hydrocortisone reduced the risk for mortality by an adjusted hazard ratio of 2.5 (95\% confidence interval: 1.11-5.56). However, nearly three-quarters of the patients received treatment with corticosteroids.

Subsequent studies have shown conflicting results, although recent meta-analysis concluded that the use of corticosteroids does not significantly affect mortality. These studies, performed mostly in adult populations, show a statistically significant greater reversibility of shock. Even if there is a reduction in mortality, this is not always significant, as the results are contradictory. For this reason, most guidelines cannot recommend one direction over another and maintain certainty.

However, we consider that most of these studies have been performed in adult population, with mortality rates between
30 and $60 \%$, and nosocomial infection rates between 20 and $40 \%$. However, pediatric population is very different than adult and the first exponent is the number of fatalities. The number of overall mortality is three to five times lower in septic pediatric patients, as it is shown in the "PROSSECIP" study. $^{3}$

There are only seven published studies specifically addressing $\mathrm{AI}$ in pediatric (not neonatal) critical illness, intensive care, sepsis, or septic shock. ${ }^{71-76}$ Six of the seven studies used different definitions of AI, and the two studies that used similar definitions in similar patient populations (meningococcal disease) found differing incidences of AI (4 vs. $17 \%) .{ }^{71,73}$ Furthermore, only two studies correlated the presence of AI by their definition with clinically important outcomes, such as longer duration of inotropes therapy and the presence of catecholamine-resistant shock. ${ }^{72,75}$ One interesting study, done by Karagüzel et $\mathrm{al}^{135}$ shows the correlation between cortisol and cytokine levels, the presence of $\mathrm{AI}$ and its prognosis. In addition, it reveals that the presence of $\mathrm{AI}$ is transient, which may encourage for a short hydrocortisone regimen. Despite the various studies, shown in - Table $\mathbf{1}$, there is no evidence to recommend or prevent the use of corticosteroids in septic pediatric patients.

\section{Secondary Effects of Cortisol}

Among the detractors of steroid therapy in septic patients, words such as superinfection and hyperglycemia are commonly used regarding other secondary effects of cortisol.

Most meta-analysis shows that low-dose hydrocortisone therapy did not increase the likelihood of superinfection in adult patients with septic shock. ${ }^{123}$

However, meta-analysis of hyperglycemia showed significant results indicating low-dose hydrocortisone increases the incidence of hyperglycemia in patients with septic shock. ${ }^{123}$ This means a possible treatment with hydrocortisone also entails strict glucose control. ${ }^{136-138}$

\section{Use of Corticosteroids}

Despite the lack of published studies on the benefits of shortterm glucocorticoid use in this patient population with a confirmed diagnosis of adrenal dysfunction, $50.9 \%$ of pediatric intensive care specialists would empirically treat hypotensive pediatric patients with corticosteroids. There are very interesting articles that report the use of corticosteroids and beliefs in cases of septic shock; to date, three studies have assessed the practice of pediatric intensive care physicians in the management of patients with shock or AI. ${ }^{78,139,140}$ All three demonstrated variability in physician practices and beliefs, but each had significant limitations including proxy reporting by medical directors, ${ }^{139}$ a differing/alternative focus, or a single-center design preventing broad-based conclusions. $^{78,139,140}$

In one study, most (81.4\%) of the pediatric intensive care specialists believed that adrenal dysfunction occurs sometimes or often in pediatric intensive care patients, whereas $41.8 \%$ of pediatric endocrinologists believed that it rarely or 


\begin{tabular}{|c|c|c|c|c|c|c|c|c|c|c|c|c|c|c|c|c|c|}
\hline 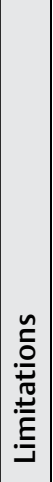 & 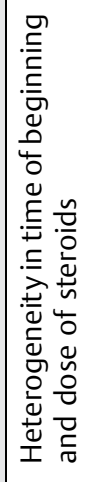 & 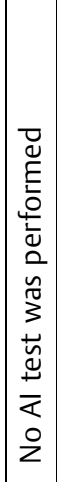 & 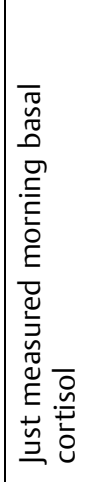 & & 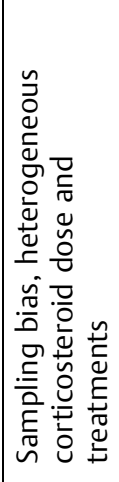 & 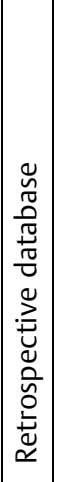 & 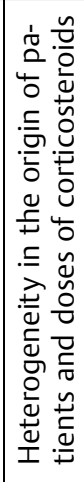 & 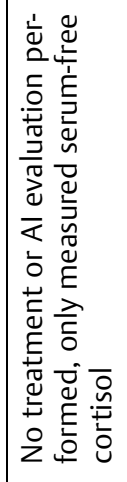 & 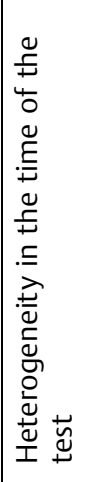 & 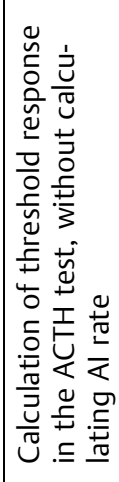 & 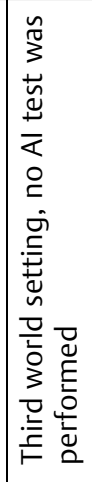 & 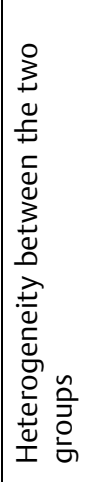 & 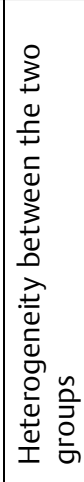 & 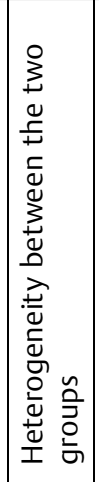 & 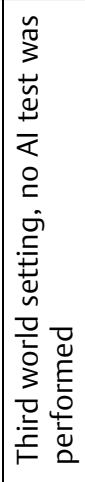 & 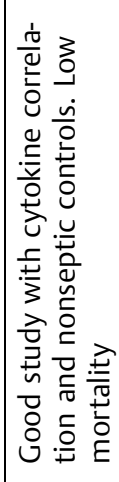 & 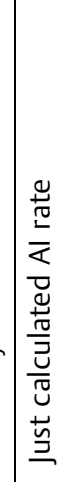 \\
\hline 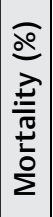 & $\stackrel{P}{r}$ & นก & 음 & กิ & & $\bar{\nabla}$ & 우 & 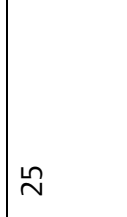 & เ & $\widetilde{\sigma}$ & $\stackrel{\nabla}{-}$ & $\stackrel{\vec{m}}{m}$ & $\tilde{m}$ & 오 & ㅇํ & $m$ & $\tilde{\sigma}$ \\
\hline 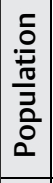 & $\frac{ \pm}{\frac{5}{2}}$ & $\frac{ \pm}{\frac{n}{2}}$ & $\frac{ \pm}{3}$ & $\frac{ \pm}{\frac{n}{z}}$ & $\frac{ \pm}{\frac{7}{2}}$ & $\frac{\frac{H}{3}}{\frac{3}{<}}$ & $\frac{ \pm}{\frac{n}{2}}$ & $\frac{ \pm}{\frac{n}{z}}$ & $\frac{ \pm}{\frac{3}{2}}$ & $\frac{ \pm}{\frac{n}{2}}$ & 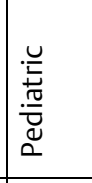 & 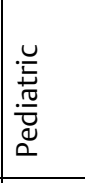 & 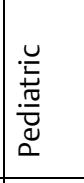 & 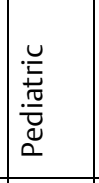 & 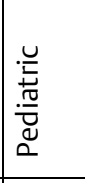 & 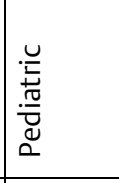 & 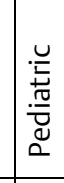 \\
\hline 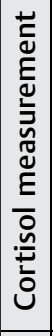 & $\begin{array}{l}\overline{\widetilde{J}} \\
\stackrel{0}{0}\end{array}$ & $\begin{array}{l}\overline{\widetilde{\pi}} \\
\stackrel{0}{0}\end{array}$ & $\begin{array}{l}\overline{\widetilde{\pi}} \\
\stackrel{0}{0}\end{array}$ & $\begin{array}{l}\overline{\widetilde{J}} \\
\stackrel{0}{0}\end{array}$ & $\begin{array}{l}\bar{\pi} \\
\stackrel{0}{0}\end{array}$ & \begin{tabular}{|l}
$\overline{\widetilde{\pi}}$ \\
$\stackrel{0}{1}$ \\
\end{tabular} & $\begin{array}{l}\overline{\widetilde{\pi}} \\
\stackrel{0}{0}\end{array}$ & 离 & 胥 & \begin{tabular}{|l}
$\overline{\widetilde{\pi}}$ \\
$\stackrel{0}{\circ}$
\end{tabular} & $\begin{array}{l}\overline{\widetilde{\pi}} \\
\stackrel{0}{\circ}\end{array}$ & 胥 & $\begin{array}{l}\overline{\widetilde{\pi}} \\
\stackrel{0}{0}\end{array}$ & $\begin{array}{l}\overline{\widetilde{\pi}} \\
\stackrel{0}{0}\end{array}$ & $\begin{array}{l}\overline{\widetilde{\pi}} \\
\stackrel{0}{\circ}\end{array}$ & $\begin{array}{l}\overline{\widetilde{\pi}} \\
\stackrel{0}{\circ}\end{array}$ & 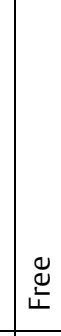 \\
\hline 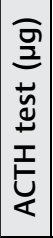 & $\stackrel{\stackrel{ }{N}}{N}$ & & & 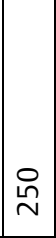 & 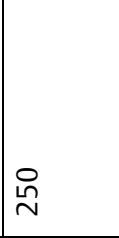 & $\stackrel{\stackrel{̊}{\aleph}}{N}$ & $\stackrel{\circ}{N}$ & & $\stackrel{\stackrel{\circ}{N}}{N}$ & $\stackrel{\stackrel{\circ}{N}}{N}$ & & $\stackrel{\stackrel{\circ}{N}}{N}$ & 光 & - & & - & - \\
\hline$\frac{\bar{Ð}}{\bar{\varepsilon}}$ & 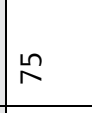 & & $\stackrel{m}{m}$ & in & in & $\stackrel{\stackrel{\sim}{\sim}}{.}$ & f & 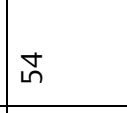 & ڤొ & & & $\nexists$ & $\curvearrowright$ & 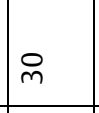 & & $\stackrel{\infty}{\sim}$ & 8 \\
\hline $\begin{array}{l}\frac{\tilde{N}}{n} \\
\frac{\tilde{v}}{0} \\
\overline{\mathrm{E}} \\
\tilde{n}\end{array}$ & : & 우 & $\stackrel{\circ}{\circ}$ & б̆ & $\stackrel{m}{r}$ & $\stackrel{\infty}{\grave{N}}$ & 守 & $\stackrel{\stackrel{n}{\cong}}{\cong}$ & டி & $\stackrel{2}{N}$ & $\mathbb{N}$ & in & $\approx$ & $\stackrel{p}{m}$ & $\stackrel{\infty}{m}$ & $\stackrel{⿱ 亠 乂}{*}$ & in \\
\hline 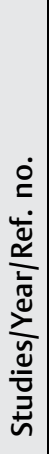 & 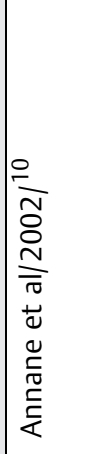 & 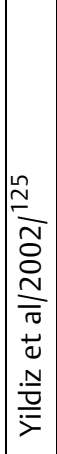 & 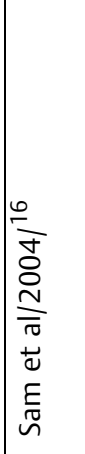 & 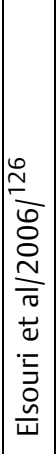 & 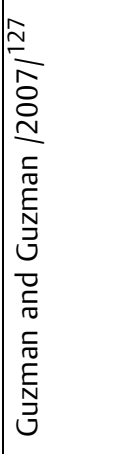 & 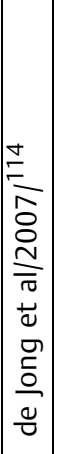 & 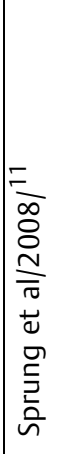 & 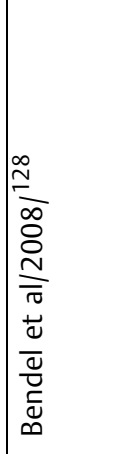 & 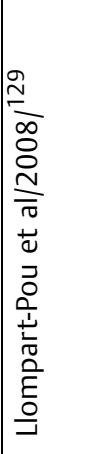 & 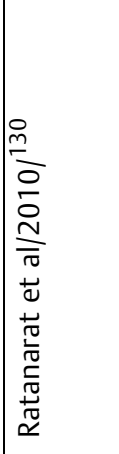 & 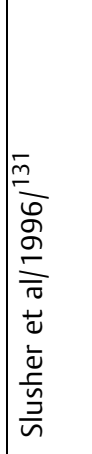 & 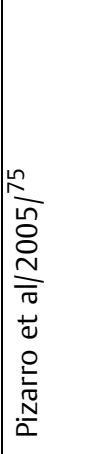 & 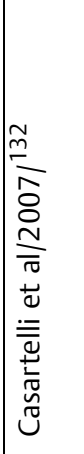 & 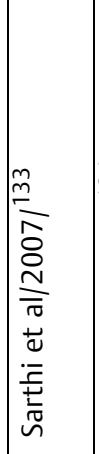 & 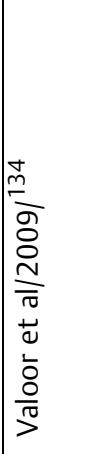 & 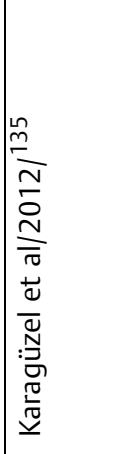 & 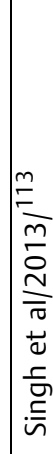 \\
\hline
\end{tabular}


never occurs in this population. ${ }^{78}$ Another study stated that steroids are regularly used in 19 pediatric intensive care units in Canada (76\%). Only one unit has a written protocol for the application of steroids. Sixteen (84\%) units who use steroids gave as their main indication persistent hypotension despite the use of inotropes. ${ }^{139}$ Physicians stated that they were more likely to prescribe steroids for septic shock than for shock following cardiac surgery or trauma. ${ }^{115}$ However, the majority of clinicians (74.2\%) admitted to using steroids in patients with fluid and/or vasoactive drug-dependent shock secondary to diagnoses other than sepsis. ${ }^{115}$

There is only one study on the number of doctors that perform adrenal testing and the type of testing conducted. Thirty-six percent of respondents reported they rarely or never conducted adrenal axis testing before giving steroids to patients in shock, whereas $37.1 \%$ of respondents stated they often or always conducted such testing prior to starting steroids. ${ }^{115}$ The most frequent type of adrenal axis testing reported as being performed was a random cortisol level (61.4\%), with 50.0\% reporting conducting low-dose $(0.5-1.0 \mu \mathrm{g})$ ACTH testing (respondents were asked to select all applicable answers). ${ }^{115}$

\section{Actual Recommendations}

The 2009 American College of Critical Care Medicine Surviving Sepsis Guidelines stated "the committee continues to maintain equipoise on the question of adjunctive steroid therapy for pediatric sepsis pending prospective randomized clinical trials." ${ }^{13}$

Low-dose hydrocortisone therapy can improve shock reversal in patients with sepsis; the therapy has no significant impact on 28-day mortality rate. The new International Guidelines for Management of Severe Sepsis and Septic Shock suggest that it is not advisable to use intravenous hydrocortisone as a treatment for adult septic shock patients if adequate fluid resuscitation and catecholamine therapy can restore hemodynamic stability. If hemodynamic stability cannot be maintained, the guidelines suggest intravenous hydrocortisone, despite the available evidence not supporting the argument that low-dose hydrocortisone should be used as a routine treatment in adult patients with septic shock. Although the evidence is not clear, most of the clinical practice guidelines agreed that children are more likely to have AI. They also recommend the administration of hydrocortisone in patients with AI confirmed by a corticotrophin test or suspected in cases of shock refractory to inotropic treatment. However, the limitations of this test for diagnosing critical illness-related corticosteroid insufficiency and the benefit of corticosteroids in both responders and nonresponders suggest that this test should not be used to select patients likely to derive benefit from corticosteroids. ${ }^{13,68,141}$ Even adult guidelines now recommend the administration of prolonged hydrocortisone and fludrocortisone therapy for any adult with dopamine-resistant septic shock. ${ }^{10}$

In the words of the leading researchers on the use of corticosteroids in septic shock: "Unfortunately, until further quality studies provide answers to the present uncertainties, clinicians will be forced to rely on their expertise in providing the art of medicine and not only the science of medicine."142

\section{References}

1 Dellinger RP, Levy MM, Rhodes A, et al; Surviving Sepsis Campaign Guidelines Committee including The Pediatric Subgroup. Surviving Sepsis Campaign: international guidelines for management of severe sepsis and septic shock, 2012. Intensive Care Med 2013;39(2):165-228

2 Levy MM, Dellinger RP, Townsend SR, et al. The Surviving Sepsis Campaign: results of an international guideline-based performance improvement program targeting severe sepsis. Intensive Care Med 2010;36(2):222-231

3 Vila Pérez D, Jordan I, Esteban E, et al. Prognostic factors in pediatric sepsis study, from the Spanish Society of Pediatric Intensive Care. Pediatr Infect Dis J 2014;33(2):152-157

4 Angus DC, Burgner D, Wunderink R, et al. The PIRO concept: P is for predisposition. Crit Care 2003;7(3):248-251

5 Vincent JL, Opal S, Torres A, Bonten M, Cohen J, Wunderink R. The PIRO concept: I is for infection. Crit Care 2003;7(3):252-255

6 Gerlach H, Dhainaut JF, Harbarth S, Reinhart K, Marshall JC, Levy M. The PIRO concept: $\mathrm{R}$ is for response. Crit Care 2003;7(3): 256-259

7 Vincent JL, Wendon J, Groeneveld J, Marshall JC, Streat S, Carlet J. The PIRO concept: $O$ is for organ dysfunction. Crit Care 2003;7(3): 260-264

8 Opal SM. Concept of PIRO as a new conceptual framework to understand sepsis. Pediatr Crit Care Med 2005;6(3, Suppl): S55-S60

9 Siami S, Bailly-Salin J, Polito A, et al. Osmoregulation of vasopressin secretion is altered in the postacute phase of septic shock. Crit Care Med 2010;38(10):1962-1969

10 Annane D, Sébille V, Charpentier C, et al. Effect of treatment with low doses of hydrocortisone and fludrocortisone on mortality in patients with septic shock. JAMA 2002;288(7):862-871 Erratum in: JAMA 2008;300(14):1652. Chaumet-Riffaut, Philippe [corrected to Chaumet-Riffaud, Philippe]

11 Sprung CL, Annane D, Keh D, et al; CORTICUS Study Group. Hydrocortisone therapy for patients with septic shock. N Engl J Med 2008;358(2):111-124

12 Toma A, Stone A, Green RS, Gray S. Steroids for patients in septic shock: the results of the CORTICUS trial. CJEM 2011;13(4): 273-276

13 Brierley J, Carcillo JA, Choong K, et al. Clinical practice parameters for hemodynamic support of pediatric and neonatal septic shock: 2007 update from the American College of Critical Care Medicine. Crit Care Med 2009;37(2):666-688

14 Hollenberg SM, Weinberger C, Ong ES, et al. Primary structure and expression of a functional human glucocorticoid receptor cDNA. Nature 1985-1986;318(6047):635-641

15 Pilkis SJ, Granner DK. Molecular physiology of the regulation of hepatic gluconeogenesis and glycolysis. Annu Rev Physiol 1992; 54:885-909

16 Sam S, Corbridge TC, Mokhlesi B, Comellas AP, Molitch ME. Cortisol levels and mortality in severe sepsis. Clin Endocrinol (Oxf) 2004;60(1):29-35

17 Carlet J. From mega to more reasonable doses of corticosteroids: a decade to recreate hope. Crit Care Med 1999;27(4):672-674

18 Matot I, Sprung CL. Corticosteroids in septic shock: resurrection of the last rites? Crit Care Med 1998;26(4):627-630

19 Meduri GU, Kanangat S. Glucocorticoid treatment of sepsis and acute respiratory distress syndrome: time for a critical reappraisal. Crit Care Med 1998;26(4):630-633

20 Schumer W. Controversy in shock research. Pro: The role of steroids in septic shock. Circ Shock 1981;8(6):667-671 
21 Sakaue M, Hoffman BB. Glucocorticoids induce transcription and expression of the alpha 1B adrenergic receptor gene in DTT1 MF2 smooth muscle cells. J Clin Invest 1991;88(2):385-389

22 Collins S, Caron MG, Lefkowitz RJ. Beta-adrenergic receptors in hamster smooth muscle cells are transcriptionally regulated by glucocorticoids. J Biol Chem 1988;263(19):9067-9070

23 Matsumura M, Kakishita H, Suzuki M, Banba N, Hattori Y. Dexamethasone suppresses iNOS gene expression by inhibiting NF-kappaB in vascular smooth muscle cells. Life Sci 2001;69(9): 1067-1077

24 Redington AE, Meng QH, Springall DR, et al. Increased expression of inducible nitric oxide synthase and cyclo-oxygenase- 2 in the airway epithelium of asthmatic subjects and regulation by corticosteroid treatment. Thorax 2001;56(5):351-357

25 Fujii E, Yoshioka T, Ishida H, Irie K, Muraki T. Evaluation of iNOSdependent and independent mechanisms of the microvascular permeability change induced by lipopolysaccharide. $\mathrm{Br} \mathrm{J}$ Pharmacol 2000;130(1):90-94

26 Chrousos GP. The hypothalamic-pituitary-adrenal axis and immunemediated inflammation. N Engl J Med 1995;332(20):1351-1362

27 Barnes PJ. Beta-adrenergic receptors and their regulation. Am J Respir Crit Care Med 1995;152(3):838-860

28 Saito T, Takanashi M, Gallagher E, et al. Corticosteroid effect on early beta-adrenergic down-regulation during circulatory shock: hemodynamic study and beta-adrenergic receptor assay. Intensive Care Med 1995;21(3):204-210

29 Putterman C. Corticosteroids in sepsis and septic shock: has the jury reached a verdict? Isr J Med Sci 1989;25(6):332-338

30 Kawamura T, Inada K, Nara N, Wakusawa R, Endo S. Influence of methylprednisolone on cytokine balance during cardiac surgery. Crit Care Med 1999;27(3):545-548 [Erratum in: Crit Care Med 1999;27(7):1404]

31 Shieh JH, Peterson RH, Moore MA. Cytokines and dexamethasone modulation of IL-1 receptors on human neutrophils in vitro. J Immunol 1993;150(8, Pt 1):3515-3524

32 Wiegers GJ, Reul JM. Induction of cytokine receptors by glucocorticoids: functional and pathological significance. Trends Pharmacol Sci 1998;19(8):317-321

33 Spriggs MK, Lioubin PJ, Slack J, et al. Induction of an interleukin-1 receptor (IL-1R) on monocytic cells. Evidence that the receptor is not encoded by a T cell-type IL-1R mRNA. J Biol Chem 1990; 265(36):22499-22505

34 Snyers L, De Wit L, Content J. Glucocorticoid up-regulation of high-affinity interleukin 6 receptors on human epithelial cells. Proc Natl Acad Sci U S A 1990;87(7):2838-2842

35 Wiegers GJ, Labeur MS, Stec IE, Klinkert WE, Holsboer F, Reul JM. Glucocorticoids accelerate anti-T cell receptor-induced $\mathrm{T}$ cell growth. J Immunol 1995;155(4):1893-1902

36 Paterson RL, Or R, Domenico JM, Delespesse G, Gelfand EW. Regulation of CD23 expression by IL- 4 and corticosteroid in human B lymphocytes. Altered response after EBV infection. J Immunol 1994;152(5):2139-2147

37 Pietzko D, Zohlnhöfer D, Graeve L, et al. The hepatic interleukin-6 receptor. Studies on its structure and regulation by phorbol 12myristate 13-acetate-dexamethasone. J Biol Chem 1993;268(6): 4250-4258

38 Franchimont D, Galon J, Vacchio MS, et al. Positive effects of glucocorticoids on T cell function by up-regulation of IL-7 receptor alpha. J Immunol 2002;168(5):2212-2218

39 Strickland RW, Wahl LM, Finbloom DS. Corticosteroids enhance the binding of recombinant interferon-gamma to cultured human monocytes. J Immunol 1986;137(5):1577-1580

40 Hawrylowicz CM, Guida L, Paleolog E. Dexamethasone up-regulates granulocyte-macrophage colony-stimulating factor receptor expression on human monocytes. Immunology 1994;83(2): 274-280 [Erratum in: Immunology 1994;83(4):681]

41 van der Goes A, Hoekstra K, van den Berg TK, Dijkstra CD. Dexamethasone promotes phagocytosis and bacterial killing by human monocytes/macrophages in vitro. J Leukoc Biol 2000; 67(6):801-807

42 Freischlag JA, Colburn MD, Quiñones-Baldrich WJ, Moore WS. Alteration of neutrophil (PMN) function by heparin, dexamethasone, and enalapril. J Surg Res 1992;52(5):523-529

43 Lloberas J, Soler C, Celada A. Dexamethasone enhances macrophage colony stimulating factor- and granulocyte macrophage colony stimulating factor-stimulated proliferation of bone marrow-derived macrophages. Int Immunol 1998;10(5): 593-599

44 Dinkel K, MacPherson A, Sapolsky RM. Novel glucocorticoid effects on acute inflammation in the CNS. J Neurochem 2003; 84(4):705-716

45 Yeager MP, Rassias AJ, Pioli PA, et al. Pretreatment with stress cortisol enhances the human systemic inflammatory response to bacterial endotoxin. Crit Care Med 2009;37(10):2727-2732

46 Gabay C. Interleukin-6 and chronic inflammation. Arthritis Res Ther 2006;8(Suppl 2):S3

47 Lauw FN, Pajkrt D, Hack CE, Kurimoto M, van Deventer SJ, van der Poll T. Proinflammatory effects of IL-10 during human endotoxemia. J Immunol 2000;165(5):2783-2789

48 Pajkrt D, Camoglio L, Tiel-van Buul MC, et al. Attenuation of proinflammatory response by recombinant human IL-10 in human endotoxemia: effect of timing of recombinant human IL-10 administration. J Immunol 1997;158(8):3971-3977

49 Druce LA, Thorpe CM, Wilton A. Mineralocorticoid effects due to cortisol inactivation overload explain the beneficial use of hydrocortisone in septic shock. Med Hypotheses 2008;70(1):56-60

50 Kaufmann I, Briegel J, Schliephake F, et al. Stress doses of hydrocortisone in septic shock: beneficial effects on opsonization-dependent neutrophil functions. Intensive Care Med 2008; 34(2):344-349

51 Lim HY, Müller N, Herold MJ, van den Brandt J, Reichardt HM. Glucocorticoids exert opposing effects on macrophage function dependent on their concentration. Immunology 2007; 122(1):47-53

52 Calandra T, Bucala R. Macrophage migration inhibitory factor (MIF): a glucocorticoid counter-regulator within the immune system. Crit Rev Immunol 1997;17(1):77-88

53 Yeager MP, Pioli PA, Wardwell K, et al. In vivo exposure to high or low cortisol has biphasic effects on inflammatory response pathways of human monocytes. Anesth Analg 2008;107(5):1726-1734

54 Warren MK, Vogel SN. Opposing effects of glucocorticoids on interferon-gamma-induced murine macrophage Fc receptor and Ia antigen expression. J Immunol 1985;134(4):2462-2469

55 Eastman HB, Fawcett TW, Udelsman R, Holbrook NJ. Effects of perturbations of the hypothalamic-pituitary-adrenal axis on the acute phase response: altered C/EBP and acute phase response gene expression in lipopolysaccharide-treated rats. Shock 1996; 6(4):286-292

56 Dhabhar FS, McEwen BS. Enhancing versus suppressive effects of stress hormones on skin immune function. Proc Natl Acad Sci U S A 1999;96(3):1059-1064

57 Matsusue S, Walser M. Healing of intestinal anastomoses in adrenalectomized rats given corticosterone. Am J Physiol 1992;263 (1, Pt 2):R164-R168

58 Cooper MS, Stewart PM. Corticosteroid insufficiency in acutely ill patients. N Engl J Med 2003;348(8):727-734

59 Mesotten D, Vanhorebeek I, Van den Berghe G. The altered adrenal axis and treatment with glucocorticoids during critical illness. Nat Clin Pract Endocrinol Metab 2008;4(9): 496-505

60 Widmer IE, Puder JJ, König C, et al. Cortisol response in relation to the severity of stress and illness. J Clin Endocrinol Metab 2005; 90(8):4579-4586

61 Vermes I, Beishuizen A. The hypothalamic-pituitary-adrenal response to critical illness. Best Pract Res Clin Endocrinol Metab 2001;15(4):495-511 
62 Selye $\mathrm{H}$. The general adaptation syndrome and the diseases of adaptation. J Clin Endocrinol Metab 1946;6:117-230

63 Vermes I, Beishuizen A, Hampsink RM, Haanen C. Dissociation of plasma adrenocorticotropin and cortisol levels in critically ill patients: possible role of endothelin and atrial natriuretic hormone. J Clin Endocrinol Metab 1995;80(4):1238-1242

64 Bornstein SR, Engeland WC, Ehrhart-Bornstein M, Herman JP. Dissociation of ACTH and glucocorticoids. Trends Endocrinol Metab 2008;19(5):175-180

65 Bornstein SR, Chrousos GP. Clinical review 104: Adrenocorticotropin (ACTH)- and non-ACTH-mediated regulation of the adrenal cortex: neural and immune inputs. J Clin Endocrinol Metab 1999;84(5):1729-1736

66 Aneja R, Carcillo JA. What is the rationale for hydrocortisone treatment in children with infection-related adrenal insufficiency and septic shock? Arch Dis Child 2007;92(2):165-169

67 Aneja R, Carcillo JA. What is the rationale for hydrocortisone treatment in children with infection-related adrenal insufficiency and septic shock? Arch Dis Child 2007;92(2):165-169

68 Marik PE. Critical illness-related corticosteroid insufficiency. Chest 2009;135(1):181-193

69 Marik PE, Zaloga GP. Adrenal insufficiency in the critically ill: a new look at an old problem. Chest 2002;122(5):1784-1796

70 Hebbar K, Rigby MR, Felner EI, Easley KA, Fortenberry JD. Neuroendocrine dysfunction in pediatric critical illness. Pediatr Crit Care Med 2009;10(1):35-40

71 Riordan FA, Thomson AP, Ratcliffe JM, Sills JA, Diver MJ, Hart CA. Admission cortisol and adrenocorticotrophic hormone levels in children with meningococcal disease: evidence of adrenal insufficiency? Crit Care Med 1999;27(10):2257-2261

72 Hatherill M, Tibby SM, Hilliard T, Turner C, Murdoch IA. Adrenal insufficiency in septic shock. Arch Dis Child 1999;80(1):51-55

73 Bone M, Diver M, Selby A, Sharples A, Addison M, Clayton P. Assessment of adrenal function in the initial phase of meningococcal disease. Pediatrics 2002;110(3):563-569

74 Menon K, Clarson C. Adrenal function in pediatric critical illness. Pediatr Crit Care Med 2002;3(2):112-116

75 Pizarro CF, Troster EJ, Damiani D, Carcillo JA. Absolute and relative adrenal insufficiency in children with septic shock. Crit Care Med 2005;33(4):855-859

76 Ando M, Park IS, Wada N, Takahashi Y. Steroid supplementation: a legitimate pharmacotherapy after neonatal open heart surgery. Ann Thorac Surg 2005;80(5):1672-1678, 1678

77 Cohen J, Ward G, Prins J, Jones M, Venkatesh B. Variability of cortisol assays can confound the diagnosis of adrenal insufficiency in the critically ill population. Intensive Care Med 2006; 32(11):1901-1905

78 Menon $\mathrm{K}$, Lawson M. Identification of adrenal insufficiency in pediatric critical illness. Pediatr Crit Care Med 2007;8(3):276-278

79 Menon K, Ward RE, Lawson ML, Gaboury I, Hutchison JS, Hébert PC; Canadian Critical Care Trials Group. A prospective multicenter study of adrenal function in critically ill children. Am J Respir Crit Care Med 2010;182(2):246-251

80 Briegel J, Schelling G, Haller M, Mraz W, Forst H, Peter K. A comparison of the adrenocortical response during septic shock and after complete recovery. Intensive Care Med 1996;22(9): 894-899

81 Zimmerman JJ, Donaldson A, Barker RM, et al; Eunice Kennedy Shriver National Institute of Child Health and Human Development Collaborative Pediatric Critical Care Research Network. Real-time free cortisol quantification among critically ill children. Pediatr Crit Care Med 2011;12(5):525-531

82 Naito Y, Fukata J, Tamai S, et al. Biphasic changes in hypothalamopituitary-adrenal function during the early recovery period after major abdominal surgery. J Clin Endocrinol Metab 1991;73(1): $111-117$
83 Schein RM, Sprung CL, Marcial E, Napolitano L, Chernow B. Plasma cortisol levels in patients with septic shock. Crit Care Med 1990;18(3):259-263

84 Nickels DA, Moore DC. Serum cortisol responses in febrile children. Pediatr Infect Dis J 1989;8(1):16-20

85 Singh UK, Jana UK. Serum prolactin and cortisol in children with some paroxysmal disorders. Indian J Pediatr 1994;61(1):57-61

86 Joosten KF, de Kleijn ED, Westerterp M, et al. Endocrine and metabolic responses in children with meningoccocal sepsis: striking differences between survivors and nonsurvivors. J Clin Endocrinol Metab 2000;85(10):3746-3753

87 Bouachour G, Tirot P, Gouello JP, Mathieu E, Vincent JF, Alquier P. Adrenocortical function during septic shock. Intensive Care Med 1995;21(1):57-62

88 Moran JL, Chapman MJ, O'Fathartaigh MS, Peisach AR, Pannall PR, Leppard P. Hypocortisolaemia and adrenocortical responsiveness at onset of septic shock. Intensive Care Med 1994; 20(7):489-495

89 McWhinney PH, Patel A, Walker E. Adrenal failure in fulminant meningococcal septicaemia: a clinical reality. Scand J Infect Dis 1990;22(6):755-756

90 Streeten DH. What test for hypothalamic-pituitary-adrenocortical insufficiency? Lancet 1999;354(9174):179-180

91 Marik PE, Zaloga GP. Adrenal insufficiency during septic shock. Crit Care Med 2003;31(1):141-145

92 Streeten DH, Anderson GH Jr, Bonaventura MM. The potential for serious consequences from misinterpreting normal responses to the rapid adrenocorticotropin test. J Clin Endocrinol Metab 1996; 81(1):285-290

93 Richards ML, Caplan RH, Wickus GG, Lambert PJ, Kisken WA. The rapid low-dose (1 microgram) cosyntropin test in the immediate postoperative period: results in elderly subjects after major abdominal surgery. Surgery 1999;125(4):431-440

94 Broide J, Soferman R, Kivity S, et al. Low-dose adrenocorticotropin test reveals impaired adrenal function in patients taking inhaled corticosteroids. J Clin Endocrinol Metab 1995;80(4):1243-1246

95 Mayenknecht J, Diederich S, Bähr V, Plöckinger U, Oelkers W. Comparison of low and high dose corticotropin stimulation tests in patients with pituitary disease. J Clin Endocrinol Metab 1998; 83(5):1558-1562

96 Rasmuson S, Olsson T, Hagg E. A low dose ACTH test to assess the function of the hypothalamic-pituitary-adrenal axis. Clin Endocrinol (Oxf) 1996;44(2):151-156

97 Tordjman K, Jaffe A, Grazas N, Apter C, Stern N. The role of the low dose (1 microgram) adrenocorticotropin test in the evaluation of patients with pituitary diseases. J Clin Endocrinol Metab 1995; 80(4):1301-1305

98 Abdu TA, Elhadd TA, Neary R, Clayton RN. Comparison of the low dose short synacthen test ( 1 microg), the conventional dose short synacthen test (250 microg), and the insulin tolerance test for assessment of the hypothalamo-pituitary-adrenal axis in patients with pituitary disease. J Clin Endocrinol Metab 1999; 84(3):838-843

99 Crowley S, Hindmarsh PC, Holownia P, Honour JW, Brook CG. The use of low doses of ACTH in the investigation of adrenal function in man. J Endocrinol 1991;130(3):475-479

100 Crowley S, Hindmarsh PC, Honour JW, Brook CG. Reproducibility of the cortisol response to stimulation with a low dose of ACTH(1-24): the effect of basal cortisol levels and comparison of low-dose with high-dose secretory dynamics. J Endocrinol 1993;136(1):167-172

101 Thaler LM, Blevins LS Jr. The low dose (1-microg) adrenocorticotropin stimulation test in the evaluation of patients with suspected central adrenal insufficiency. J Clin Endocrinol Metab 1998;83(8):2726-2729

102 Agwu JC, Spoudeas H, Hindmarsh PC, Pringle PJ, Brook CG. Tests of adrenal insufficiency. Arch Dis Child 1999;80(4):330-333 
103 Beishuizen A, Thijs LG, Vermes I. Patterns of corticosteroidbinding globulin and the free cortisol index during septic shock and multitrauma. Intensive Care Med 2001;27(10):1584-1591

104 Hamrahian AH, Oseni TS, Arafah BM. Measurements of serum free cortisol in critically ill patients. N Engl J Med 2004;350(16): 1629-1638

105 Arafah BM. Hypothalamic pituitary adrenal function during critical illness: limitations of current assessment methods. J Clin Endocrinol Metab 2006;91(10):3725-3745

106 Törnhage CJ. Salivary cortisol for assessment of hypothalamicpituitary-adrenal axis function. Neuroimmunomodulation 2009; 16(5):284-289

107 Gozansky WS, Lynn JS, Laudenslager ML, Kohrt WM. Salivary cortisol determined by enzyme immunoassay is preferable to serum total cortisol for assessment of dynamic hypothalamicpituitary-adrenal axis activity. Clin Endocrinol (Oxf) 2005; 63(3):336-341

108 Estrada-Y-Martin RM, Orlander PR. Salivary cortisol can replace free serum cortisol measurements in patients with septic shock. Chest 2011;140(5):1216-1222

109 Loriaux L. Glucocorticoid therapy in the intensive care unit. N Engl J Med 2004;350(16):1601-1602

110 Ho JT, Al-Musalhi H, Chapman MJ, et al. Septic shock and sepsis: a comparison of total and free plasma cortisol levels. J Clin Endocrinol Metab 2006;91(1):105-114

111 Arafah BM, Nishiyama FJ, Tlaygeh H, Hejal R. Measurement of salivary cortisol concentration in the assessment of adrenal function in critically ill subjects: a surrogate marker of the circulating free cortisol. J Clin Endocrinol Metab 2007;92(8):2965-2971

112 Patel RS, Shaw SR, Macintyre H, McGarry GW, Wallace AM. Production of gender-specific morning salivary cortisol reference intervals using internationally accepted procedures. Clin Chem Lab Med 2004;42(12):1424-1429

113 Singh SN, Rathia SK, Awasthi S, Singh A, Bhatia V. Salivary cortisol estimation to assess adrenal status in children with fluid unresponsive septic shock. Indian Pediatr 2013;50(7):681-684

114 de Jong MF, Beishuizen A, Spijkstra JJ, Groeneveld AB. Relative adrenal insufficiency as a predictor of disease severity, mortality, and beneficial effects of corticosteroid treatment in septic shock. Crit Care Med 2007;35(8):1896-1903

115 Menon K, McNally JD, Choong K, et al. A survey of stated physician practices and beliefs on the use of steroids in pediatric fluid and/ or vasoactive infusion-dependent shock. Pediatr Crit Care Med 2013;14(5):462-466

116 Knighton JD, Woodock TE, Hough M. Adrenal failure in the critically ill. Br J Anaesth 1999;82(1):152-153

117 Briegel J, Forst H, Haller M, et al. Stress doses of hydrocortisone reverse hyperdynamic septic shock: a prospective, randomized, double-blind, single-center study. Crit Care Med 1999;27(4): 723-732

118 Bollaert PE, Charpentier C, Levy B, Debouverie M, Audibert G, Larcan A. Reversal of late septic shock with supraphysiologic doses of hydrocortisone. Crit Care Med 1998;26(4):645-650

119 Oppert M, Reinicke A, Gräf KJ, Barckow D, Frei U, Eckardt KU. Plasma cortisol levels before and during "low-dose" hydrocortisone therapy and their relationship to hemodynamic improvement in patients with septic shock. Intensive Care Med 2000; 26(12):1747-1755

120 Cronin L, Cook DJ, Carlet J, et al. Corticosteroid treatment for sepsis: a critical appraisal and meta-analysis of the literature. Crit Care Med 1995;23(8):1430-1439

121 Annane D, Bellissant E, Bollaert PE, Briegel J, Keh D, Kupfer Y. Corticosteroids for severe sepsis and septic shock: a systematic review and meta-analysis. BMJ 2004;329(7464):480

122 Annane D, Bellissant E, Bollaert PE, et al. Corticosteroids in the treatment of severe sepsis and septic shock in adults: a systematic review. JAMA 2009;301(22):2362-2375
123 Wang C, Sun J, Zheng J, et al. Low-dose hydrocortisone therapy attenuates septic shock in adult patients but does not reduce 28 day mortality: a meta-analysis of randomized controlled trials. Anesth Analg 2014;118(2):346-357

124 Menon K, McNally D, Choong K, Sampson M. A systematic review and meta-analysis on the effect of steroids in pediatric shock. Pediatr Crit Care Med 2013;14(5):474-480

125 Yildiz O, Doganay M, Aygen B, Güven M, Keleştimur F, Tutuû A. Physiological-dose steroid therapy in sepsis [ISRCTN36253388]. Crit Care 2002;6(3):251-259

126 Elsouri N, Bander J, Guzman JA. Relative adrenal insufficiency in patients with septic shock; a close look to practice patterns. J Crit Care 2006;21(1):73-77

127 Guzman JA, Guzman CB. Adrenal exhaustion in septic patients with vasopressor dependency. J Crit Care 2007;22(4):319-323

128 Bendel S, Karlsson S, Pettilä V, Loisa P, Varpula M, Ruokonen E; Finnsepsis Study Group. Free cortisol in sepsis and septic shock. Anesth Analg 2008;106(6):1813-1819

129 Llompart-Pou JA, Raurich JM, Ibáñez J, Riesco M, Ayestarán JI. Immediate hemodynamic response to steroid treatment in septic shock [in Spanish]. Med Intensiva 2008;32(8):385-390

130 Ratanarat R, Promsin P, Srivijitkamol A, Leemingsawat C, Permpikul C. Diagnosis of corticosteroid insufficiency in Thai patients with septic shock. J Med Assoc Thai 2010;93(Suppl 1):S187-S195

131 Slusher T, Gbadero D, Howard C, et al. Randomized, placebocontrolled, double blinded trial of dexamethasone in African children with sepsis. Pediatr Infect Dis J 1996;15(7):579-583

132 Casartelli CH, Garcia PC, Branco RG, Piva JP, Einloft PR, Tasker RC. Adrenal response in children with septic shock. Intensive Care Med 2007;33(9):1609-1613

133 Sarthi M, Lodha R, Vivekanandhan S, Arora NK. Adrenal status in children with septic shock using low-dose stimulation test. Pediatr Crit Care Med 2007;8(1):23-28

134 Valoor HT, Singhi S, Jayashree M. Low-dose hydrocortisone in pediatric septic shock: an exploratory study in a third world setting. Pediatr Crit Care Med 2009;10(1):121-125

135 Karagüzel G, Atay S, Değer O, İmamoğlu M, Ökten A, Karagüzel G. The effects of three specific conditions related to critical care on adrenal function in children. Intensive Care Med 2012;38(10):1689-1696

136 Hermanides J, Vriesendorp TM, Bosman RJ, Zandstra DF, Hoekstra $\mathrm{JB}$, Devries JH. Glucose variability is associated with intensive care unit mortality. Crit Care Med 2010;38(3):838-842

137 Egi M, Bellomo R, Stachowski E, French CJ, Hart G. Variability of blood glucose concentration and short-term mortality in critically ill patients. Anesthesiology 2006;105(2):244-252

138 Moghissi ES, Korytkowski MT, DiNardo M, et al; American Association of Clinical Endocrinologists; American Diabetes Association. American Association of Clinical Endocrinologists and American Diabetes Association consensus statement on inpatient glycemic control. Diabetes Care 2009;32(6):1119-1131

139 Hildebrandt T, Mansour M, Al Samsam R. The use of steroids in children with septicemia: review of the literature and assessment of current practice in PICUs in the UK. Paediatr Anaesth 2005; 15(5):358-365

140 Benken ST, Hutson TK, Gardiner RL, Wheeler DS. A single-center review of prescribing trends and outcomes of corticosteroid replacement therapy in critically ill children with septic shock. Open Crit Care Med J 2010;3:51-56

141 Marik PE, Pastores SM, Annane D, et al; American College of Critical Care Medicine. Recommendations for the diagnosis and management of corticosteroid insufficiency in critically ill adult patients: consensus statements from an international task force by the American College of Critical Care Medicine. Crit Care Med 2008;36(6):1937-1949

142 Bauer W, Ball J, Grounds M. Unanswered questions from Corticus and pragmatic suggestions. Crit Care 2008;12(4):426, discussion 426 